\title{
Should we use the hyperthermic intraperitoneal chemotherapy in the management of ovarian cancer? A literature review
}

\author{
Nicolae Bacalbasa*1, Olivia lonescu², Irina Balescu ${ }^{3}$ \\ ${ }^{1}$ Carol Davila University of Medicine and Pharmacy, Bucharest, Romania \\ ${ }^{2}$ Bucur Maternity Hospital, Bucharest, Romania \\ ${ }^{3}$ Ponderas Hospital, Bucharest, Romania
}

Received: July 26, 2015

DOI: $10.5430 /$ jst.v6n1p21
Accepted: November 9, 2015

Online Published: December 2, 2015

\begin{abstract}
Rationale: Epithelial ovarian cancer (EOC) is a relatively chemosensitive malignancy which begins, and most frequently disseminates by intraperitoneal seeding. Intraperitoneal chemotherapy (IP) is a route of drug delivery that allows the direct infusion of the chemotherapeutic agents into the peritoneal cavity. It has been proven to be efficient and with lower systemic side effects in comparison to the intravenous (IV) route. The combination between hyperthermia and intraperitoneal chemotherapy (Hyperthermic intraperitoneal chemotherapy) has a synergistic killing effect on the malignant cells and appears to be feasible in the treatment of EOC.
\end{abstract}

Objective: To review the current literature and discuss the use of HIPEC in the course of the EOC treatment: as first line medical treatment, at the time of cytoreductive surgery (CS), postoperative adjuvant IP chemotherapy and HIPEC, and for recurrent disease focusing on the survival benefit, mortality rates, morbidity, adverse effects and limitations.

Method: Medline, Pubmed, and the Cochrane Central Register of Controlled Trials (CENTRAL) were investigated for English language articles about the role of HIPEC in women with primary EOC, of any FIGO stage. The analysis was restricted to retrospective studies, randomized and nonrandomized controlled clinical trials, and gynecological oncology journals. The selected information included data on feasibility, overall survival (OS), quality of life, and comparison with standard IV chemotherapy in terms of complications, toxicity and anticancer effects.

Conclusion: Hyperthermia of the IP chemotherapy solution increases the cytotoxicity of the drug in the peritoneal cavity and its systemic effects on the tumor peritoneal nodules. Although initial investigators presented encouraging survival outcomes when HIPEC was used in recurrent EOC, further studies are necessary in order to incorporate HIPEC as a front-line treatment of EOC or as an adjuvant therapy. More research is required for defining the possible roles of HIPEC within the spectrum of other treatments for EOC including repeated normothermic IP chemotherapy, early postoperative IP chemotherapy, and novel and biological agents.

Key Words: Ovarian cancer, Hyperthermia, Cytoreductive surgery, Chemotherapy

\footnotetext{
*Correspondence: Nicolae Bacalbasa; Email: nicolae_bacalbasa@yahoo.ro; Address: Carol Davila University of Medicine and Pharmacy, Eroilor Sanitari Bld, Bucharest, Romania.
} 


\section{INTRODUCTION}

Epithelial ovarian cancer (EOC) is still one of the most common cause of cancer death in females despite its innate properties which should allow an efficient treatment. ${ }^{[1]}$ It is considered a malignancy which origins from the ovarian surface epithelium and confines itself to the peritoneal surface. ${ }^{[2]}$ Because the initial symptoms are rather nonspecific, the majority of cases are being diagnosed in an advanced stage, III or IV conform International Federation of Gynecology and Obstetrics (FIGO). In these stages, distant metastases and peritoneal carcinomatosis are already present. Patients with OC of all stages have a 5-year survival rate of almost $50 \%$ in contrast to less than $25 \%$ in women diagnosed in an advanced stage. ${ }^{[3]}$

Maximal cytoreductive surgery followed by 6 cycles of platinum-based chemotherapy is the cornerstone treatment in EOC. $80 \%$ of women may completely respond to chemotherapy, however most of them develop recurrences with a poor prognostic. ${ }^{[4]}$ The diameter of the residual tumor (RD) is the most significant prognostic factor which can influence survival rates. It has been proved that, if the percentage of patients with no gross RD after CS increases with $10 \%$, then the median duration of survival increases with $5.5 \%$. ${ }^{[5]}$

As the main route of dissemination in $\mathrm{OC}$ is through the peritoneum, a direct administration of the cytotoxic drugs into the peritoneal cavity significantly reduces the systemic toxic effects which may appear after the intravenous (IV) administration. ${ }^{[6]}$ A meta-analysis of all randomized studies with OC patients treated with normo-thermic chemotherapy with cisplatin and paclitaxel via either the i.v. route only or combined i.v. and i.p. routes demonstrated that women who received i.p. chemotherapy have better survival outcomes. ${ }^{[7]}$ In a study conducted by the Gynecologic Oncology Group172 (GOG-172), the median survival for patients who were at least partially submitted to i.p. chemotherapy was 65.6 months compared to 49.6 months after i.v. drug administration. ${ }^{[8]}$ In spite of better survival benefits, the reported median progression-free survival (PFS) was only 5 months longer than the control group (23.8 months vs. 18.3 months), and the reported recurrence was almost $65 \%$.

The benefits from hyperthermic intraperitoneal chemotherapy are: ${ }^{[9-11]}$

- it has a tumoricidal effect;

- influences DNA crosslinking and adduct formation;

- facilitates a better penetration of the drug into the peritoneal metastases.

Spratt et al. constructed a system to deliver hyperthermic chemotherapy to the peritoneal cavity in a canine and human model, and since then HIPEC has been included in the treatment of gastric, appendiceal, colorectal or endometrial cancer. $^{[12-15]}$ This review completes the wide range of data that has been already published with an attention to the role of HIPEC in EOC, and has the purpose to present the efficacy of HIPEC and how it could be used in order to obtain best survival outcomes for women with EOC.

\section{TECHNIQUE OF HIPEC}

The method through which HIPEC can be delivered are the following: ${ }^{[16]}$

- the "closed" method;

- the "open" method;

- the "coliseum" method;

- a technique which uses a "cavity acrylic expander".

The above mentioned methods are based on a system of pumps which allow the free circulation of the heated chemotherapeutical agents in the peritoneal cavity. The procedure takes place in three steps each of them requiring different lengths of time: between 30 and 45 minutes for initiation, 30-90 minutes for perfusion of the solution and 15 minutes for take down. Totally, the surgical procedure extends with 90-150 minutes. The whole equipment is then removed, the saline and anti-adhesion solutions are administered and the wound is sutured. ${ }^{[2]}$ The mechanism of action is represented in the following Figure 1:

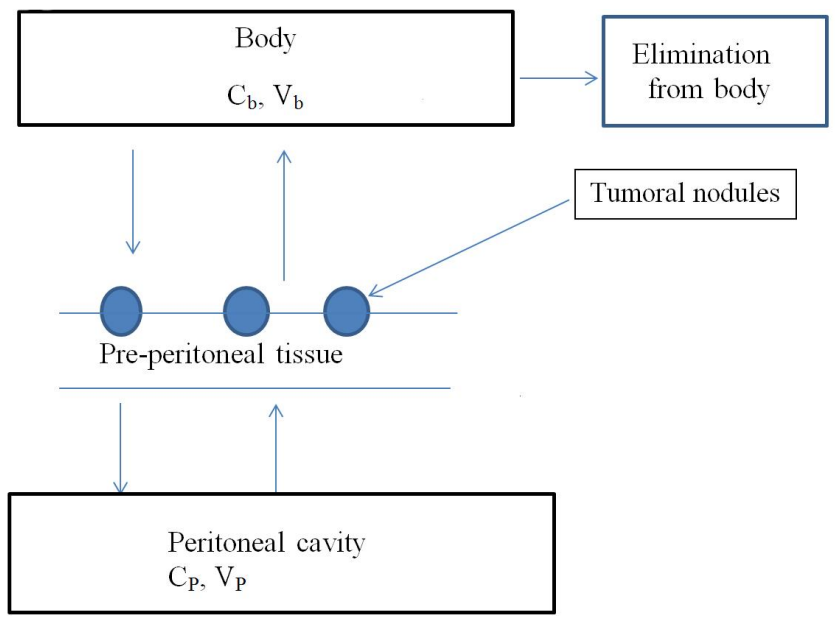

Figure 1. HIPEC-mechanism of action. $\mathrm{C}_{b}=$ Drug concentration in the blood; $\mathrm{V}_{b}$ : Volume of distribution of the drug in the body; $\mathrm{C}_{p}$ : The free drug concentration in the peritoneal fluid; $\mathrm{V}_{p}$ : Volume of the peritoneal cavity. The rate of transfer of the drugs into the peritoneal cavity can be calculated by multiplying the permeability area with the overall concentration difference between the peritoneal cavity and the blood. The area of permeability controls this transfer. Rate of mass transfer $=$ Permeability Area $\times$ $\left(\mathrm{C}_{p}-\mathrm{C}_{b}\right)$ 
Heat combined with IP chemotherapy results in a synergistic effect which increases the efficacy of the cytotoxic drug. Recent clinical studies have shown the resulted peritoneal drug concentration obtained after HIPER delivery is between 10 and 20 times higher than after a systemic delivery route. ${ }^{[17]}$ Moreover, HIPEC does not require access into the peritoneal cavity through a special device, hence it can be good tolerated with a lower rate of complications associated with the use of a special catheter. ${ }^{[18]}$

Improvements in the laparoscopic techniques have made possible the performance of laparoscopic assisted heated intraoperative intraperitoneal chemotherapy which facilitates and adhesiolysis, cytoreduction, and chemotherapy delivery. ${ }^{[19]}$

\subsection{Performing HIPEC during primary CS and interval debulking surgery}

The possibility to implement HIPEC during primary CS was first described by Steller et al. ${ }^{[20]}$ and favourable arguments for a HIPEC safely delivering are:

(1) it has effect even on the RD obtained at the end of surgery;

(2) it can easily penetrate all surfaces of the peritoneal cavity, hence reaching any small tumor, optimally microscopic or free-floating;

(3) the possibility of an earlier delivery of treatment than normally. ${ }^{[21]}$

However, the available data cannot answer the question whether HIPEC at the time of primary CS can bring survival benefits and improvement life quality of women with EOC ${ }^{[22]}$ further studies being required to establish the optimal IP chemotherapy regimen in the setting of primary CS.

Neo-adjuvant chemotherapy for two or three cycles before surgery can increase the chance of obtaining a complete tumor resection and has less peri- and postoperative complications. ${ }^{[23]}$ Because of the small number of patients and the heterogeneity of information with regard to the criteria of patient selection and therapeutic strategy, a comparison between neo-adjuvant chemotherapy followed by interval debulking and HIPEC and primary CS and HIPECC in terms of efficiency and survival benefits is still not reasonable. ${ }^{[24]}$ Apart from the advantages mentioned above, performing HIPEC during ID surgery allows the multidisciplinary team to finalize HIPEC system planification and arrangement before the surgery. ${ }^{[25,26]}$ Similarly, due to the nonrandomized nature of data and the low evidence level of the studies relevant statements are difficult to be outlined. ${ }^{[2,27]}$

Published by Sciedu Press

\subsection{Postoperative adjuvant IP chemotherapy and HIPEC}

IP chemotherapy can be planned after primary CS as an adjuvant therapy. It may be administered in the early postoperative period, or once the normal peristalsis returns.

In the former case, chemotherapy delivery is much more effective because the chemoperfusate diffuses can easier diffuse into the residual tumor nodules before formation of adhesions. ${ }^{[28]}$

Even though in the meta-analyses of randomized controlled trials good results as concerns DFS and OS after IP chemotherapy have been observed, in the recent GOG-172 randomized trial, the toxicity associated complications have prevented $68 \%$ of patients from the IP arm to complete their planned six cycles of IP adjuvant chemotherapy. ${ }^{[8]}$ In the study of Walker et al, ${ }^{[29]} 119$ patients received IP chemotherapy after being submitted to optimal CS. Of these, 40 of patients (34\%) suffered from catheter-related complications, 45 patients $(38 \%)$ could not tolerate the IP treatment, and 34 patients $(29 \%)$ abandoned the treatment as a result of unexpected complications or disease progression. Despite the supporting level 1 evidence, and due to the high rate of catheter and route-of-delivery complications, currently, adjuvant IP chemotherapy is not ready for routine clinical use.

With regard to the incorporation of HIPEC when disease volume is at its lowest volume and all peritoneal surfaces and tumors are exposed, there is no agreement that HIPEC could contribute to achieving better survival rates. Gori et al. ${ }^{[30]}$ reported a study of 51 patients submitted to optimal CS (RD $<2 \mathrm{~cm}$ ) followed by chemotherapy with cisplatin and cyclophosphamide delivered through the $i . v$ route. Of these, 32 patients received second-look laparotomy and HIPEC. The rest of 19 patients refused the second-look laparotomy and were included in the control group. The HIPEC group had a median follow-up of 64.4 months in contrast to 46.4 months for the control group.

Similarly, Bae et al. ${ }^{[31]}$ presented the results of a study on 44 patients with stage III OC who received second-look laparotomy and HIPEC with carboplatin $(\mathrm{n}=30)$ and paclitaxel $(\mathrm{n}$ $=14$ ) as adjuvant chemotherapy. The control group consisted of 24 patients treated only with second-look laparotomy. After finalizing second-look laparotomy, an i.v. consolidation chemotherapy was mandatory for all patients. The HIPEC group had a 3-year PFS rate of 56.3\% and an overall 5-year survival rate of $66.1 \%$, while for the control group the results were $56.3 \%$, and $31.3 \%$ respectively.

The above presented studies, as well as the existing reports 
in the specialized literature would be more enlightening if they included explanations of the definitions of platinum sensitivity and time of recovery, the range of median OS reported for patients undergoing CRS and HIPEC in the literature (between 24 and 106 months) the upper range of which has only been reported with CS followed by systemic and normothermic IP chemotherapy. ${ }^{[32]}$

\subsection{The survival results, mortality and morbidity of HIPEC in advanced and recurrent $\mathrm{OC}$}

The studies concerning the use of HIPEC in recurrent OC are large, heterogenous, nonrandomized, and include patients with persistent disease and poor prognosis, and cannot weigh against series reporting CS alone for recurrent disease. ${ }^{[33]}$ Prognostic factors of survival in recurrent or persistent OC patients treated with CS and HIPEC are: ${ }^{[26,34-38]}$

- interval from diagnosis to HIPEC;

- peritoneal cancer index;

- age;

- performance status;

- presence of lymph node metastasis;

- the extent of RD prior to the performance of HIPEC.

The overall-progression free survival differs between the published studies. In women younger than 55 years with recurrent OC, the 5-year survival rate was $75 \% .^{[36]}$

The conclusions of the studies included in this review are summarized in Table 1. ${ }^{[2]}$

Table 1. The results obtained after using HIPEC for epithelial ovarian cancer (either in persistent or recurrent disease)

\begin{tabular}{|c|c|c|c|c|c|c|c|c|c|c|}
\hline Study & $\begin{array}{l}\text { No. of } \\
\text { patients (n) }\end{array}$ & Drug used & Dose & Min & $\mathbf{T}\left({ }^{\circ} \mathrm{C}\right)$ & OS & $\begin{array}{l}2-Y r \\
\text { survival } \\
(\%)\end{array}$ & $\begin{array}{l}\text {-Yr } \\
\text { survival } \\
(\%)\end{array}$ & $\begin{array}{l}5-Y r \\
\text { survival } \\
(\%)\end{array}$ & $\begin{array}{l}\text { Progression } \\
\text {-free } \\
\text { survival }\end{array}$ \\
\hline $\begin{array}{l}\text { Deraco } \\
\text { et al. }{ }^{[34]}\end{array}$ & 27 & Cisplatin & $25 \mathrm{mg} / \mathrm{m}^{2} / \mathrm{l}$ & 60 & 42.5 & & 55 & & & 21.8, median \\
\hline $\begin{array}{l}\text { van der } \\
\text { Vange } \\
\text { et al. }{ }^{[39]}\end{array}$ & 5 & Cisplatin & $50 / 75 \mathrm{mg} / \mathrm{m}^{2}$ & 90 & 40 & & 40 & & & \\
\hline $\begin{array}{l}\text { Panteix } \\
\text { et al. }{ }^{[40]}\end{array}$ & 16 & Cisplatin & $60 / 80 / 100 \mathrm{mg}$ & 90 & $41-43$ & & & 37.5 & & \\
\hline $\begin{array}{l}\text { de Bree } \\
\text { et al. }{ }^{[41]}\end{array}$ & 19 & Doceta-xel & $75 \mathrm{mg} / \mathrm{m}^{2}$ & 120 & $41-43$ & & 43 & & & \\
\hline $\begin{array}{l}\text { Zanon } \\
\text { et al. }{ }^{[42]}\end{array}$ & 30 & Cisplatin & $100 / 150 \mathrm{mg} / \mathrm{m}^{2}$ & 60 & $\begin{array}{l}41.5- \\
42.5\end{array}$ & $\begin{array}{l}\text { 28.1, } \\
\text { median }\end{array}$ & 60 & & & \\
\hline $\begin{array}{l}\text { Raspagliesi } \\
\text { et al. }{ }^{[37]}\end{array}$ & 40 & $\begin{array}{l}\text { Cisplatin/ } \\
\text { Mitomycin } \\
\text { or cisplatin/ } \\
\text { doxoru-bicin }\end{array}$ & $\begin{array}{l}25 / 3.3 \mathrm{mg} / \\
\mathrm{m}^{2} / 1 \text { or } \\
43 / 15.25 \mathrm{mg} / 1\end{array}$ & & 42.5 & $\begin{array}{l}41.4, \\
\text { mean }\end{array}$ & & & 15 & 23.9, mean \\
\hline $\begin{array}{l}\text { Rufián } \\
\text { et al. }{ }^{[36]}\end{array}$ & 33 & Paclitaxel & $60 \mathrm{mg} / \mathrm{m}^{2}$ & 60 & $41-43$ & $\begin{array}{l}57, \\
\text { mean }\end{array}$ & & 51 & & \\
\hline $\begin{array}{l}\text { Helm } \\
\text { et al. }{ }^{[35]}\end{array}$ & 18 & $\begin{array}{l}\text { Cisplatin or } \\
\text { mitomycin }\end{array}$ & $\begin{array}{l}100 \mathrm{mg} / \mathrm{m}^{2} \text { or } \\
40 \mathrm{mg}\end{array}$ & 90 & $42-43$ & $\begin{array}{l}31 \text {, } \\
\text { median }\end{array}$ & 42 & & & 10 , median \\
\hline $\begin{array}{l}\text { Cotte } \\
\text { et al. }{ }^{[38]}\end{array}$ & 81 & Cisplatin & $\begin{array}{l}20 \mathrm{mg} / \mathrm{m}^{2} / \mathrm{l} \\
\max 80 \mathrm{mg}\end{array}$ & 90 & $44-46$ & $\begin{array}{l}\text { 28.4, } \\
\text { median }\end{array}$ & & & & 19.2, median \\
\hline
\end{tabular}

The above presented outcomes are not sufficiently conclusive as they have included women with advanced or recurrent $\mathrm{OC}$ and good prognostic factors and have excluded patients with persistent disease after primary CS and platinum-based intravenous chemotherapy. As mentioned in Table 1, the median DFS are between 13-74 months in advanced OC, and between 13 and 74 months in recurrent $\mathrm{OC}$, while the 3 -year and 5-year survival rates are higher compared to the results from the control group (which received only surgical treatment).

Recently, a randomized trial of CRS and HIPEC based on cisplatin $\left(100 \mathrm{mg} / \mathrm{m}^{2}\right)$ and paclitaxel $\left(175 \mathrm{mg} / \mathrm{m}^{2}\right)$ for recur- rent FIGO stage IIIC and IV EOC reported a better mean survival in the HIPEC arm (26.7 vs. 13.4 months), even though randomization has been performed before the CS. ${ }^{[45]}$

It is worth to mention that the complication rates reported for CS and HIPEC summarizes the complication rates of the surgical and chemotherapeutic treatment. The mortality rates for HIPEC in advanced and recurrent OC are between $0-5 \%$ and $0-10 \%$ respectively, higher than the rates in the cohort treated with adjuvant IP chemotherapy without HIPEC (0-2\%). In the latter case, only the complications resulted from the six cycles of treatment have been reported. ${ }^{[39,42-44]}$ Furthermore, in recurrent disease, patients have previously 
undergone radical surgery with the aim of achieving a complete primary CS. The data on mortality rates are similar to those reported in other gastrointestinal malignancies. ${ }^{[45,46]}$

The reviewed information on HIPEC in advanced and recurrent EOC for 256 patients has also pointed out an significantly increased rate of morbidity for HIPEC-, between 0 to 40\%. ${ }^{[20,26,39,45-47]}$ These include:

- hematological toxicity (4.3\%) when oxaliplatin was used;

- increase of the creatinine value $(3.9 \%)$ when cisplatin was used;

- anastomotic gastrointestinal leaks (1.6\%) and perforations $(2.3 \%)$ as a result of localized heat and cytotoxic drugs;

- septic complications (10\%) which include: wound infection $(4.3 \%)$, peritonitis $(0.8 \%)$, and abscess $(1.2 \%)$.

The rate of severe morbidity after $\mathrm{CS}$ alone in recurrent $\mathrm{OC}$ is $11 \% .^{[48]}$

\subsection{Limitations of HIPEC and choice of chemotherapeu- tic agents}

Cisplatin has been used in the majority of HIPEC studies on OC, but doxorubicin, mitomycin $\mathrm{C}$, oxaliplatin, paclitaxel and gemcitabine have also been employed. ${ }^{[21,27,29,36,37,49-51]}$ The optimal agent should have the following characteristics: ${ }^{[2,28]}$

- hydrosolubility;

- no or low peritoneal clearance, high peritoneal concentration, and systemic clearance;

- increased cytotoxic effect with the help of hyperthermia.

The predictable restraints for the use of HIPEC are: ${ }^{[7,52]}$

- the necessity to deliver drugs into the peritoneal cavity as the dissemination routes in OC can be also through the lymphatic and venous system or through direct invasion in the diaphragm. In these cases, IP delivery is not effective.

\section{REFERENCES}

[1] Seigal R, Naishadham D, Jemal A. Cancer statistics. CA Cancer J Clin. 2012; 62(1): 10-29.

[2] Helm CW. The role of hyperthermic intraperitoneal chemotherapy (HIPEC) in ovarian cancer. The Oncologist. 2009; 14: 68394. PMid:19608639. http://dx.doi.org/10.1634/theoncolo gist. 2008-0275

Published by Sciedu Press
- The achieved concentrations after IP administration of platinum components are high so that further IP instillation may not be reasonable. IP administration may be limited to women with microscopic RD after debulking surgery, the reported tumor penetration depth being between 1 and $2 \mathrm{~mm}$.

- The above outlined complications after HIPEC are generally known so that better scores of life quality can be obtained after IP rather than with standard IV therapy.

- HIPEC necessitates experienced gynaecological oncologists who can perform debulking surgery, as well as medical oncologists and nurses who were trained for the management of complications or other technical issues.

\section{Conclusion}

Despite the large number of reports who presented their results after using HIPEC in EOC, further prospective large randomized controlled trails are required in order to identify the potential role of HIPEC in OC, accept HIPEC as part of the treatment protocol for recurrent and persistent OC.

Further research regarding the following issues is necessary:

- a better understanding of mechanisms of action of hyperthermia;

- a possible use of HIPEC as a targeted molecular therapy; IP administration may be limited to women with microscopic RD after debulking surgery, the reported tumor penetration depth being between 1 and $2 \mathrm{~mm}$.

- other modalities to deliver HIPEC such as the possibility to develope a microwave technology in order to deliver whole-abdomen hyperthermia;

- the possibility to create international collaboratory centers which can offer data regarding indications, technique ,mortality and morbidity rates, and prognostic factors.

\section{CONFLICTS OF INTEREST Disclosure}

The author declares that there is no conflict of interest statement.
[3] Parkin DM, Bray F, Ferlay J, et al. Global cancer statistics. CA Cancer J Clin. 2005; 55: 74-108. PMid:15761078. http://dx . doi.o $\mathrm{rg} / 10.3322 /$ canjclin.55.2.74

[4] Bookman MA, Mc Guire III WP, Kilpatrick D, et al. Carboplatin and paclitaxel in ovarian carcinoma: a phase I study of the gynecologic oncology group. Journal of Clinical Oncology. 1996; 14(6): 1895-902. PMid:8656258. 
[5] Bristow RE, Tomacruz RS, Armstrong DK, et al. Survival effect of maximal cytoreductive surgery for advanced ovarian carcinoma during the platinumera: a meta-analysis. Journal of Clinical Oncology. 2002; 20(5): 1248-59. PMid:11870167. http://dx.doi.org/10. $1200 / J C 0.20 .5 \cdot 1248$

[6] Markman M. Intraperitoneal chemotherapy in the management of malignant disease. Expert Rev Anticancer Ther. 2001; 1: 142 8. PMid:12113122. http://dx.doi.org/10.1586/14737140.1. 1.142

[7] Jaaback K, Johnson N. Intraperitoneal chemotherapy for the initial management of primary epithelial ovarian cancer. Cochrane Database Syst Rev. 2006; (1): CD005340. http://dx.doi.org/10.1002 /14651858.cd005340.pub2

[8] Armstrong DK, Bundy B, Wenzel L, et al. Gynecologic Oncology Group. Intraperitoneal cisplatin and paclitaxel in ovarian cancer. N Engl J Med. 2006; 354: 34-43. PMid:16394300. http: //dx.doi.org/10.1056/NEJMoa052985

[9] Istomin YP, Zhavrid EA, Alexandrova EN, et al. Dose enhancement effect of anticancer drugs associated with increased temperature in vitro. Exp Oncol. 2008; 30: 56-9. PMid:18438342.

[10] Mohamed F, Marchettini P, Stuart OA, et al. Thermal enhancement of new chemotherapeutic agents at moderate hyperthermia. Ann Surg Oncol. 2003; 10: 463-8. PMid:12734097. http://dx.doi.org/1 $0.1245 /$ ASO .2003 .08 .006

[11] de Bree E, Theodoropoulos PA, Rosing H, et al. Treatment of ovarian cancer using intraperitoneal chemotherapy with taxanes: From laboratory bench to bedside. Cancer Treat Rev. 2006; 32: 47182. PMid:16942841. http://dx.doi.org/10.1016/j.ctrv. 20 06.07 .006

[12] Fujimoto S, Takahashi M, Mutou T, et al. Improved mortality rate of gastric carcinoma patients with peritoneal carcinomatosis treated with intraperitoneal hyperthermic chemoperfusion combined with surgery. Cancer. 1997; 79: 884-91. http://dx.doi.org/10.1002/(SICI ) 1097-0142(19970301) 79:5<884: :AID-CNCR3>3 . 0.CO;2-C

[13] Sugarbaker PH, Chang D. Results of treatment of 385 patients with peritoneal surface spread of appendiceal malignancy. Ann Surg Oncol. 1999; 6: 727-31. http://dx.doi.org/10.1007/s10434-9 99-0727-7

[14] Witkamp AJ, de Bree E, Kaag MM, et al. Extensive cytoreduc tive surgery followed by intra-operative hyperthermic intraperitoneal chemotherapy with mitomycin-C in patients with peritoneal carcinomatosis of colorectal origin. Eur J Cancer. 2001; 37: 979-84. http://dx.doi.org/10.1016/S0959-8049(01)00058-2

[15] Helm CW, Toler CR, Martin RS 3rd, et al. Cytoreduction and intraperitoneal heated chemotherapy for the treatment of endometrial carcinoma recurrent within the peritoneal cavity. Int J Gynecol Cancer. 2007; 17: 204-9. PMid:17291254. http://dx.doi.org/10. $1111 / j .1525-1438.2006 .00751 . x$

[16] Esquivel J, Sugarbaker PH, Helm CW. Techniques of delivering hyperthermic intraperitoneal chemotherapy. In: Helm CW, Edwards RP, eds. Intraperitoneal Cancer Therapy. Totowa, NJ: Human Press Inc. 2007: 163-77. http://dx.doi.org/10.1007/978-1-59745-1 95-6_11

[17] Kusumoto T, Holden SA, Ara G, et al. Hyperthermia and platinum complexes: time between treatments and synergy in vitro and in vivo. Int J Hyperthermia. 1995; 11(4): 575-86. PMid:7594810. http://dx.doi.org/10.3109/02656739509022491

[18] Sugarbaker PH. Laboratory and clinical basis for hyperthermia as a component of intracavitary chemotherapy. Int J Hyperthermia. 2007; 23(5): 431-42. PMid:17701534. http://dx.doi .org/10.1080/0 2656730701455318
[19] Gesson-Paute A, Ferron G, Thomas F, et al. Pharmacokinetics of oxaliplatin during open versus laparoscopically assisted heated intraoperative intraperitoneal chemotherapy (HIPEC): An experimental study. Ann Surg Oncol. 2008; 15: 339-44. PMid:17943387. http://dx.doi.org/10.1245/s10434-007-9571-9

[20] Steller MA, Egorin MJ, Trimble EL, et al. A pilot phase I trial of continuous hyperthermic peritoneal perfusion with high-dose carboplatin as primary treatment of patients with small-volume residual ovarian cancer. Cancer Chemother Pharmacol. 1999; 43: 106-14. PMid:9923815. http://dx.doi.org/10.1007/s002800050870

[21] Cotte E, Glehen O, Mohamed F, et al. Cytoreductive surgery and intraperitoneal chemo-hyperthermia for chemo-resistant and recurrent advanced epithelial ovarian cancer: Prospective study of 81 patients. World J Surg. 2007; 31: 1813-20. PMid:17629740. http: //dx.doi.org/10.1007/s00268-007-9146-8

[22] Di Giorgio A, Naticchioni E, Biacchi D, et al. Cytoreductive surgery (peritonectomy procedures) combined with hyperthermic intraperitoneal chemotherapy (HIPEC) in the treatment of diffuse peritoneal carcinomatosis from ovarian cancer. Cancer. 2008; 113: 315-25. PMid:18473354. http://dx.doi.org/10.1002/cncr. 23553

[23] Bristow RE, Eisenhauer EL, Santillan A, et al. Delaying the primary surgical effort for advanced ovarian cancer: A systematic review of neoadjuvant chemotherapy and interval cytoreduction. Gynecol Oncol. 2007; 104: 480-90. PMid:17166564. http://dx.doi.org /10.1016/j ·ygyno.2006.11.002

[24] Spirtos NM, Pisani AL, Chen ND, et al. Commenting on "future directions in the surgical management of ovarian cancer." Gynecol Oncol. 2004; 94: 236-8. PMid:15262152. http://dx.doi.org/1 $0.1016 / j$. ygyno.2004.02.038

[25] Vergote I, van Gorp T, Amant F, et al. Timing of debulking surgery in advanced ovarian cancer. Int J Gynecol Cancer. 2008; 18(suppl 1): 11-9. PMid:18336393. http://dx.doi.org/10.1111/j.152 5-1438.2007.01098. $\mathrm{x}$

[26] Reichman TW, Cracchiolo B, Sama J, et al. Cytoreductive surgery and intraoperative hyperthermic chemoperfusion for advanced ovarian carcinoma. J Surg Oncol. 2005; 90: 51-6; discussion 56-8. PMid:15844187. http://dx.doi.org/10.1002/jso. 20243

[27] Ryu KS, Kim JH, Ko HS, et al. Effects of intraperitoneal hyperthermic chemotherapy in ovarian cancer. Gynecol Oncol. 2004; 94 : 325-32. PMid:15297169. http://dx.doi.org/10.1016/j.ygy no. 2004.05 .044

[28] Chan DL, Morris DL, Rao A, et al. Intraperitoneal chemotherapy in ovarian cancer: a review of tolerance and efficacy. Cancer Management and Research. 2012: 4.

[29] Walker JL, Armstrong DK, Huang HQ, et al. Intraperitoneal catheter outcomes in a phase III trial of intravenous versus intraperitoneal chemotherapy in optimal stage III ovarian and primary peritoneal cancer: a Gynecologic Oncology Group study. Gynecol Oncol. 2006; 100(1): 27-32. PMid:16368440. http://dx.doi.org/10.1016/j .ygyno.2005.11.013

[30] Gori J, Castaño R, Toziano M, et al. Intraperitoneal hyperthermic chemotherapy in ovarian cancer. Int J Gynecol Cancer. 2005; 15: 2339. PMid:15823105. http://dx.doi.org/10.1111/j.1525-143 8.2005.15209.x

[31] Bae JH, Lee JM, Ryu KS, et al. Treatment of ovarian cancer with paclitaxel- or carboplatin-based intraperitoneal hyperthermic chemotherapy duringsecondary surgery. Gynecol Oncol. 2007; 106: 193-200. PMid:17466362. http://dx.doi.org/10.1016/j.ygy no. 2007.03 .019

[32] Chi DS, Eisenhauer EL, Lang J, et al. What is the optimal goal of primary cytoreductive surgery for bulky stage IIIC epithelial ovarian car- 
cinoma (EOC)? Gynecol Oncol. 2006; 103: 559-64. PMid:16714056. http://dx.doi.org/10.1016/j.ygyno.2006.03.051

[33] Centre for Evidence Based Medicine. Oxford Center for EvidenceBased Medicine-Levels of Evidence. Available at http://www.ce bm.net/levels_of_evidence.asp, accessed March 11, 2009.

[34] Deraco M, Rossi CR, Pennacchioli E, et al. Cytoreductive surgery followed by intraperitoneal hyperthermic perfusion in the treatment of recurrent epithelial ovarian cancer: A phase II clinical study. Tumori. 2001; 87: 120-6. PMid:11504363.

[35] Helm CW, Randall-Whitis L, Martin RS 3rd, et al. Hyperthermic intraperitoneal chemotherapy in conjunction with surgery for the treatment of recurrent ovarian carcinoma. Gynecol Oncol. 2007; 105: 90-6. PMid:17173957. http://dx.doi.org/10.1016/j.ygyno .2006 .10 .051

[36] Rufián S, Munoz-Casares FC, Briceño J, et al. Radical surgeryperitonectomy and intraoperative intraperitoneal chemotherapy for the treatment of peritoneal carcinomatosis in recurrent or primary ovarian cancer. J Surg Oncol. 2006; 94: 316-24. PMid:16917864. http://dx.doi.org/10.1002/jso. 20597

[37] Raspagliesi F, Kusamura S, Campos Torres JC, et al. Cytoreduction combined with intraperitoneal hyperthermic perfusion chemotherapy in advanced/recurrent ovarian cancer patients: The experience of National Cancer Institute of Milan. Eur J Surg Oncol. 2006; 32: 671-5. PMid:16621425. http://dx.doi.org/10.1016/j.ejso. 2006.03 .011

[38] Cotte E, Glehen O, Mohamed F, et al. Cytoreductive surgery and intraperitoneal chemo-hyperthermia for chemo-resistant and recurrent advanced epithelial ovarian cancer: Prospective study of 81 patients. World J Surg. 2007; 31: 1813-20. PMid:17629740. http: //dx.doi.org/10.1007/s00268-007-9146-8

[39] van der Vange N, van Goethem AR, Zoetmulder FA, et al. Extensive cytoreductive surgery combined with intra-operative intraperitoneal perfusion with cisplatin under hyperthermic conditions (OVHIPEC) in patients with recurrent ovarian cancer: A feasibility pilot. Eur J Surg Oncol. 2000; 26: 663-8. PMid:11078613. http://dx.doi.org/10.1053/ejso.2000.0978

[40] Panteix G, Beaujard A, Garbit F, et al. Population pharmacokinetics of cisplatin in patients with advanced ovarian cancer during intraperitoneal hyperthermia chemotherapy. Anticancer Res. 2002; 22: 1329-36. PMid: 12168946

[41] de Bree E, Romanos J, Michalakis J, et al. Intraoperative hyperthermic intraperitoneal chemotherapy with docetaxel as second-line treatment for peritoneal carcinomatosis of gynaecological origin. Anticancer Res. 2003; 23: 3019-27. PMid:12926156.

[42] Zanon C, Clara R, Chiappino I, et al. Cytoreductive surgery and intraperitoneal chemohyperthermia for recurrent peritoneal carci- nomatosis from ovarian cancer. World J Surg. 2004; 28: 10405. PMid:15573262. http://dx.doi .org/10.1007/s00268-004 $-7461-\mathrm{x}$

[43] Piso P, Dahlke MH, Loss M, et al. Cytoreductive surgery and hyperthermic intraperitoneal chemotherapy in peritoneal carcinomatosis from ovarian cancer. World J Surg Oncol. 2004; 2: 21-7. PMid:15222884. http://dx.doi.org/10.1186/1477-7819-2 $-21$

[44] Yoshida Y, Sasaki H, Kurokawa T, et al. Efficacy of intraperitoneal continuous hyperthermic chemotherapy as consolidation therapy in patients with advanced epithelial ovarian cancer: A long-term followup. Oncol Rep. 2005; 13: 121-5. http://dx.doi.org/10.3892 /or.13.1.121

[45] Van der Speeten K, Stuart A, Sugarbaker P. Pharmacology of cancer chemotherapy drugs for hyperthermic intraperitoneal peroperative chemotherapy in epithelial ovarian cancer. World J Obstet Gynecol 2013 November 10; 2(4): 143-52. http://dx.doi.org/10.5317 /wjog.v2.i4.143

[46] Herzog TJ. The role of heated intraperitoneal chemotherapy (HIPEC) in ovarian cancer: hope or hoax? Ann Surg Oncol. 2012; 19: 3998-4000. PMid:22833000. http://dx.doi.org/10.1245/s10 434-012-2521-1

[47] Elattar A, Bafaloukos D, Winter-Roach BA, et al. Optimal primary surgical treatment for advanced epithelial ovarian cancer. Cochrane Database Syst Rev. 2011; 10(8): CD007565. http://dx.doi.org /10.1002/14651858.cd007565.pub2

[48] Burger RA, Brady MF, Bookman MA, et al. Incorporation of bevacizumab in the primary treatment of ovarian cancer. N Engl J Med. 2011; 365: 2473-83. PMid:22204724. http://dx.doi.org/10. 1056/NEJMoa1104390

[49] Munkarah AR, Coleman RL. Critical evaluation of secondary cytoreduction in recurrent ovarian cancer. Gynecol Oncol. 2004; 95: 273-80. PMid:15491746. http://dx.doi.org/10.1016/j.ygy no. 2004.09.018

[50] Istomin YP, Zhavrid EA, Alexandrova EN, et al. Dose enhancement effect of anticancer drugs associated with increased temperature in vitro. Exp Oncol. 2008; 30: 56-9. PMid:18438342.

[51] Rein DT, Volkmer AK, Volkmer J, et al. Systemic administration of bevacizumab prolongs survival in an in vivo model of platinum pre-treated ovarian cancer. Oncol Lett. 2012; 3: 530-4. http://dx.doi.org/10.3892/ol.2012.553

[52] Bookman MA. First-line chemotherapy in epithelial ovarian cancer. Clin Obstet Gynecol. 2012; 55: 96-113. PMid:22343232. http: //dx.doi.org/10.1097/GRF.0b013e31824b45da 